\title{
Challenges for the Professional and Continuous Education of Human Resources Managers in Hong Kong
}

\author{
Juni Chan, Krystal Consultancy, Hong Kong \\ John Burgess, University of Newcastle, Australia
}

\begin{abstract}
This paper sets out to examine three issues. First, using a sample of the 27 listed companies in Hong Kong, it examines the public reporting of HR issues to discover what this reveals about the functions normally attributed to HR managers in large listed Hong Kong organizations. Second, it reports on the interviews conducted with senior executives from a sample of these listed companies regarding the required attributes of $H R$ managers. The third section discusses the challenges and processes for improving competencies of HR managers through professional education in Hong Kong.
\end{abstract}

Keywords: Human Resources Competency, Human Resources Reporting, Human Resources Managers, Professional Education, Strategic Human Resources Management, Listed companies, Hong Kong

\section{Introduction}

$\mathrm{H}$

UMAN RESOURCES MANAGEMENT (HRM) originated from the factory system in the later part of 1800 s and developed to an increased specialisation of HR functions in the twentieth first century (Analoui, 2007; Wynter-Palmer, 2007). It can potentially contribute to the corporate strategy, business strategy or functional strategy of the organizations (Hurtado, 2007). HRM is a source of competitive advantage since employees are the most valuable resource for organizations (Ormanidi and Stringa, 2008; Pedrini, 2007; Ulrich, 2005; Guest, Michie, Conway and Sheehan, 2003; Wright, Gardner and Moynihan, 2003; Finnie and Early, 2002; Bacon, 2001; Marciano, 1995). It creates value in the organizations by developing and applying intellectual input and manual effort in the workplace, particularly in high skilled sectors (Wyatt, 2008). An organization with a brand as a talent developer increases the confidence of investors (Younger, Smallwood and Ulrich, 2007). Improving the performance of employees is found to have positive results for organizations (Chow, 2004; Boulton, Libert and Samek, 2000; Barney, 1995).

There is evidence of a significant correlation between HR managers' capabilities and the company performance (Karami, Jones and Kakabadse, 2008). The critical strategic contribution of a HR manager is to lead in the organizational design for growth and to guide line managers to address talent management issues (Mohrman, 2007). In view of this, HR managers are expected to expand their competencies (RBL, 2009). Personal, organizational, managerial and functional competencies are the key areas for HR managers to create competitive advantages in organizations (Brewster, Farndale and Ommeren, 2000). HR managers need to develop new skills to deliver sustained competitive success in organizations (Bacon, 2001). They are expected to be credible activists, culture and change stewards, talent managers, strategy architects, operational executors and business allies (RBL, 2009). These roles 
have evolved from the early four factor role model: strategic partners, administrative experts, change agents and employee champions (RBL, 2009).

In practice, many HR managers are still seen as performing traditional administrative roles and their ability to develop and implement strategic programs within organizations has been questioned in many countries (Chanda, Krishna and Shen, 2006; Tamkin, Reilly and Strebler, 2006; Darien, 2005; Sheehan and Scafidi, 2005; Birchfield, 2003; Ulrich, 1998). Research has found that HR managers are not performing a strategic function within organisations (PwC, 2008; Othman, Abdul-Ghani and Arshad, 2001). Similarly, HR managers in Hong Kong have been found to perform largely administrative functions (HKIHRM, 2008; Lam and Schaubroeck, 1998; Yeung, Cheung, So, Lui and Lui, 1998).

In this study we look at the functions that HR managers perform from an examination of public documents and through formal interviews with senior managers of selected Hong Kong listed companies.

\section{Background Literature}

Organizational performance and HRM link has been well researched over the past two decades (Birdi, Clegg, Patterson, Robinson, Stride, Wall and Wood, 2008; Nishii, Lepak and Schneider, 2008). HRM is identified as a valuable, rare, imperfectly imitable and imperfectly substitutable strategic resource for the organisation (Birdi et al, 2008). This leads to an extensive attention by academics and practitioners to the development of HRM capabilities (Becker and Huselid, 2006). Strategic HRM is concerned with formulation and implementation strategies, developing employees' skills and strengthening the status of HRM in the organisation (Becton and Schraeder, 2009).

However, Chief Executives Officers tend to picture themselves as strategists of the organisations conceiving big ideas whilst everyone else including HR managers work on the small details (Nishii et al, 2008). An extensive survey of 4,741 executives in over 81 countries reported that transforming a HR manager into a strategic partner is a major challenge for many organisations (BCG/WFPMA, 2008).

There are challenges for organizations to validate empirically HR strategies through using performance indicators (Marr, 2005; Papalexandris and Panayotopoulous, 2004). Various studies call for the development and application of HRM assessment tools in order to monitor the performance and to identify the contribution of HRM to organizations (Adams, 2004; Spanos, Zaralis and Lioukas, 2004; Walker, 2001). There has been a recent development towards extending organizational reporting beyond financial data to include social, environmental and ethical aspects of a business (Balmer, Fukukawa and Gray, 2007). This extended reporting also includes many aspects of HRM including core labour standards and rights as listed by the International Labor Office (KPMG, 2008; Oxfam, 2008).

Despite this trend, research on corporate governance has reported a low transparency of organizations in the East Asian region (Eldomiaty and Chong, 2006; Welford, 2004). Organizations tend to stick to required financial reporting requirements and are reluctant to extend the breadth or depth of their reporting. Previous research has found that HR managers in Hong Kong are influenced by Chinese culture, with an emphasis on harmony, saving face and non confrontation, and this tends to mitigate against an expanded HR role or HR reporting (Chau and Chan, 2005). HR managers in Hong Kong were found to focus on traditional administrative functions, especially recruitment and selection activities, and an absence of 
strategic engagement (HKIHRM, 2008). A large study by Oxfam also reported minimal HR reporting: 67 per cent of 43 constituents listed companies scored zero in HR reporting (Oxfam, 2008).

\section{The Research Questions}

Apart from the above Oxfam study (2008), there have been very few studies of HRM positioning and reporting in Hong Kong. Such HR research has been mainly directed towards major economies such as the US, UK or Japan (Spanos et al, 2004). This paper addresses the following questions:

RQ1.Is there public evidence that selected Hong Kong organizations are engaging in HR reporting?

RQ2. What issues are incorporated into HR?

RQ3.Do executives for selected companies see the need for extended HR reporting and a strategic role for HR management in their organizations?

RQ4.Do executives for selected companies perceive that HR managers and HR divisions have the required competencies to behave strategically?

\section{Research Methods}

Content analysis of public documents was conducted on 27 listed companies that included the top 20 listed companies in terms of market capitalisation plus another seven smaller listed companies. Prior research has suggested that large listed companies were more likely to have extensive and sophisticated HR systems (Pedrini, 2007; Welford, 2004). The public documents analysed included the company web sites and the company annual reports for 2007. The documents were analysed using a code developed in a study of HR reporting in major Finnish companies by Vuontisjärvi (2006).

Invitation letters for interview were sent to the corporate executives at the level of CEO or HR Director, or at similar position of the 27 companies. 11 accepted the invitation and attended the interviews that lasted around one hour. There were seven males and four females, with more than 15 years of experience, from secondary education to doctoral qualifications. There were four CEOs (thereafter referred as CEO1 to CEO4) and seven HR Directors (thereafter referred as HRD1 to HRD7).

\section{Findings: Documentary Analysis}

Since the annual reports must meet certain disclosure requirements, it is possible that HR practices that are outside of these disclosure requirements will go unreported. A review on web sites offers an opportunity for companies to disclose issues related to HR practices beyond statutory reporting requirements.

Prior research reported that HR reporting in Hong Kong was much less in terms of depth and coverage than in other OECD economies (Oxfam, 2008; Welford, 2005) and was generally driven by need to satisfy statutory reporting requirements. In annual reports, 5 per cent of the total coverage was devoted to HR disclosures. 51.8 per cent was under 'Finance' section. 1 per cent was HR designated pages, mainly on senior management staff. On corporate 
web sites, 15.1 per cent in corporate web sites were devoted to HR disclosures. 59 per cent was under 'Directors, Management and Supervisor'. One company had a dedicated HR section while one company did not have any HR related disclosures, except for reporting the profile of their directors. Only a few HR managers were listed as part of the management team ( 22 per cent in the annual reports and 7 per cent in the web sites). Table 1 summarizes the findings from annual reports and web sites. The table reports the data in terms of frequency and space, that is, how many companies reported particular issues and what percentage of reports were devoted to these issues.

Table 1: HR Items Reported in Annual Reports and Web sites

\begin{tabular}{|l|l|l|}
\hline Themes Reported & $\begin{array}{l}\text { Annual reports } \\
\text { (Ranking in \%) }\end{array}$ & $\begin{array}{l}\text { Corporate websites } \\
\text { (Ranking in \%) }\end{array}$ \\
\hline Training and staff development & 38 & 61 \\
\hline Pay and benefits & 12 & 10 \\
\hline Participation and staff involvement & 15 & 0 \\
\hline $\begin{array}{l}\text { Values and principles including } \\
\text { HR objectives }\end{array}$ & 1 & 15 \\
\hline Employee health and well-being & 18 & 2 \\
\hline $\begin{array}{l}\text { Reporting and Measurement of } \\
\text { policies }\end{array}$ & 3 & 2 \\
\hline Employment policy & 6 & 0 \\
\hline Security in employment & 1 & 14 \\
\hline Equal opportunities & 5 & 6 \\
\hline Work-life balance & 1 & 2 \\
\hline $\begin{array}{l}\text { Remarks: Highest three items in terms of percentages in Bold. } \\
\text { Figures did not add up to a total of } 100 \% \text { because of rounding. }\end{array}$ \\
\hline
\end{tabular}

As shown in Table 1, most HR disclosures varied in the form and coverage in the public documents. The inconsistency makes it difficult to assess how the HR managers can translate their HR strategy into action. The most extensive HR coverage was devoted to training and development in the annual reports (38 per cent) and the corporate web sites (61 per cent). Such reporting was rather descriptive and lacked a link with the strategic direction of the organizations. Employee health and well being ranked second in the annual reports (18 per cent), but ranked second last on the web sites ( 2 per cent). Participation and staff involvement (15 per cent) ranked third in the annual reports but ranked the last on the web sites ( 0 per cent).

The different reporting details revealed a lack of recognised assessment tools (Wyatt, 2008; Eldomiaty and Chong, 2006; Adams, 2004; Spanos et al, 2004; Vuontisjärvi, 2006; Walker, 2001). Measurement of HR policies was the second least reported item in annual reports ( 3 per cent) and corporate web sites ( 2 per cent). 


\section{Findings: Interviews}

This section reports the observation from the interviews with corporate executives on the need for HR reporting and strategic HRM; their views on the required competencies of HR managers. Findings show that most respondents considered reporting as unnecessary or unwilling to report.

"There is no need to report because HR reports do not offer the information for business analysis." (CEO2)

"Salary package is a sensitive issue and the remuneration package of the top five executives should not be disclosed to the public." (CEO3)

"Investors and financial analysts are not interested in the HR data." (CEO4)

"Since HR reporting is a voluntary disclosure, there is no need to report." (HRD5)

Without strategic values in the HR reporting, some respondents chose intentionally not to disclose beyond statutory requirements or treated reporting as a public relations activity.

“An annual report is prepared for reporting financial figure. We don't have much HR reporting in annual report." (HRD5)

"There is no need to report on HR functions. The end result of HR activity is more important than the reporting it." (CEO1)

As a result, respondents did not know what to report.

"We haven't started the HR reporting yet. We do not know how to report and the HR department is preparing the data and the report format now." (HRD1)

"We do not have much to report and are not ready to report." (HRD7)

There were divergent views towards having awards as a major metric in measuring HR's performance. Some respondents were rather proud to describe their awards that garnered the management's appreciation towards HR's performance.

"We are accredited the awards from professional bodies because awards show that we have done a lot in that particular area." (CEO1)

"I'm satisfied with the HRM's performance. It is also witnessed from employee attitude survey that scored 85 per cent at employees' satisfaction." (CEO4)

"The motivation effect of award accreditation is shown from the Staff Attitude Survey.

The Management is also satisfied with the award winning." (HRD4)

Some respondents considered that awards were not good indicators of HR performance. They stated:

"There is no universal standard. HR performance varies with industries and companies." (HRD6)

"Awards in Hong Kong are measuring the staff relations rather than strategic HRM." (HRD7) 
Most respondents considered the HR department as an administrative department. HR managers were seen as lacking the skills required in conducting strategic HR functions (Becton and Schraeder, 2009).

"The function of HRM is like the arms and legs to ensure the properly functioning of a person." (HRD2)

"HRM acts like a bridge between management and general employees." (HRD3)

"Our HR manager implements the HR practices after the Management has made the decision. HR reporting does not indicate strategic orientation." (CEO2)

"HRM is like the blood of a person; it needs to integrate different strategic business units." (CEO3)

HR managers were criticized for having poor time management priorities (Darien, 2005).

"Our HR Director is unable to build corporate culture to translate the business strategies into vision and aspiration to employees. Many HR departments in Hong Kong take a dual role in HRM and office administrative tasks." (CEO2)

Some HR managers were unaware of the importance of reporting, lacked communication skills and had limited awareness of organizational change (Vickers, 2007). It made it difficult for them engage in any form of HR reporting that was strategic to the organization.

"We often let the Communication Department do the HR reporting." (HRD3)

"Our HR team is not up the standard and not able to translate the company's vision into action.” (CEO4)

Some respondents considered that they should not proclaim their performance. This can be partly explained by Chinese culture that promotes preservation of the harmony or 'guanxi' within the organizations (Ahlstrom, Foley, Young and Chan, 2005).

"We prefer not to publish the result so as to avoid 'finger pointing' at the under-performing strategic business units." (HRD5)

"Asian culture is reserved and not accustomed to boost what they have done." (HRD6)

"Our company operates like a family business. The top management makes all decision and HR department is not involved strategically in the business operation." (CEO2)

Some HR respondents adopted a low profile and this appeared to conform to a commonly held and deep seated view by executives in Hong Kong (Chow, 2004; Lam and Schaubroeck, 1998).

"HRM should take the role of a service provider. I prefer not to push the HRM to a strategic function." (HRD3)

"The more you report, the more queries that you invite. So it is better not to report beyond statutory requirement." (HRD5)

From the interviews, respondents revealed a few challenges for the HR managers who claim to be strategic. First, they have to show a perceived linking of organizational performance 
to HR activities to assist in the investment decision of potential investors (Petty, Ricceri and Guthrie, 2008).

"HR reporting indicates the Company's commitment toward employees." (CEO1)

"Public HR reporting enhances corporate image and is also a driving force for employees' involvement." (HRD6)

Second, some respondents suggested that sizable organizations should have more HR reporting to illustrate how to benchmark their operations.

"We haven't thought of the need to report HR issues. But our Company has expanded in the past few years. Maybe, it is time to consider more reporting." (CEO3)

"The leading company of the industry should report more." (HRD5)

Third, to be professionally recognised, HR managers are required to contribute especially during tough market situation (O'Neil, 2009; Moss, 2008). Respondents recalled how they worked strategically in the organizations during economic downturn.

"During the Asian Economic crisis, the HR department has played an important role in downsizing on cost cutting and talent management." (CEO2)

"In early 2000s, the HR Department designed the performance scheme. Staff and Line departments supported this scheme." (HRD6)

Forth, HR managers are expected to have passion towards the organizations.

"The HR Manager should facilitate the Line Departments in staff management. He needs passion towards the Company and the experience to manage the strategic HR issues." (CEO4)

Lastly, recognition from the management is important for the strategic development of HR functions.

"I am invited by the business managers to present the business proposal to clients. This shows that HRM has it impact on the organization's business." (HRD7)

"When given the stage to perform, HR practitioners can perform well." (HRD6)

"The Management realizes HR's effort and direction through trust, communication and appropriate HR initiatives." (HRD2)

"Our HR Director is given more changes to be involved in the strategic meeting." (CEO4)

\section{The Analysis of the Findings}

From the above findings, this study shows a demand for increasing disclosures in social reporting. More HR disclosures, in form of standardized performance indicators, can reveal HR's performance to various stakeholders. As the companies under studied are the major companies, they should take the lead and show the way in developing strategic HR programs in the Hong Kong setting. Organisations need more HR reporting and not simply in terms 
of reporting facts and figures, but to meet global reporting standards. Furthermore, it is suggested that developing intellectual capital assists organizations to cope with economic uncertainty (Tayles, Pike and Sofian, 2007). The global financial crisis is placing greater pressure on organizations to be more transparent in their business operations. Such claims for reporting and transparency are also relevant to HR operations (Oxfam, 2008).

HR managers in the sample companies were considered as incapable of developing strategic HR programs and did not treat the HR function as strategic, reflecting views found elsewhere (Vickers, 2007). Without demonstrating the competencies of HR managers, it is difficult to gain support and trust from senior management. HR managers need to be visible and to be perceived as competent especially during turbulent business environments. Hong Kong organizations have to be alert towards increasing their competitiveness with more HR managers' involvement, particularly needed during the challenging economic situation. The strategic development of HR managers is complicated by the mindset of power distance in the Asian hierarchy being low profile, preserving harmony, giving face and avoiding confrontation. They tried not to take risk in initiating new HR initiatives that may not be understood or be found to be unpopular.

There is the potential to develop a more expansive role for HR managers in Hong Kong. HR professionalism is a decisive factor in increasing the competitiveness of Hong Kong and there is a need to reposition the roles of HR managers in their organizations. To be recognised, being visible and to be perceived as competent are the key success factors.

\section{Conclusions}

The study shows that the public HR reporting was not developed, nor did it have a strategic orientation within the organisation. Training and development was the most frequently reported item and most of the HR coverage was reported under the financial reports. Without knowing the strategic value of HRM and perceiving the HR managers being not capable, organizations rarely report the HR's performance to their stakeholders. While interviews with corporate executives indicated the importance of human assets in the strategic development of companies, it is surprising that the examined Hong Kong companies have a traditional and narrow perspective regarding HR reporting and strategic HRM. Strategic HRM will be built up when there is trust and communication between the HR manager and corporate executives; and the competencies in developing and implementing strategic HR programs being recognised.

The study is limited by a small number of Hong Kong listed companies and the interviews were confined to even fewer organisations. The documentary analysis and the surveys should not be seen to be representative of the total picture in Hong Kong. However, the issues raised are relevant ones in terms of prior research findings. This calls for more in depth analysis of internal HR documents and processes. Future research could also track developments in public disclosures through time or more follow up interviews with senior corporate executives to establish whether the public reports accurately reflect the position of HR within organisations.

\section{References}

Adams, C. (2004), The ethical, social, environmental reporting - performance portrayal gap, Accounting, Auditing and Accountability Journal, 17, 5, pp. 731-757. 
Ahlstrom, D., Foley, S., Young, M. and Chan, E. (2005), Human Resources Strategies in post-WTO China, Thunderbird International Business Review, 47 , 3, pp. 263-285.

Analoui, F. (2007), Strategic Human Resource Management, Thomson Learning, London, UK.

Bacon, N. (2001), Review article: Comparative advantage through human resources management: best practice or core competence, Human Relations, 54, 3, pp.361-372.

Balmer, J., Fukukawa, K. and Gray, E. (2007), The Nature and Management of Ethical Corporate Identity: a commentary on corporate identity, corporate social responsibility and ethics, Journal of Business Ethics, 76, pp. 7-15.

Barney, J. (1995), Looking Inside for Competitive Advantage, Academy of Management Executive, 9, 4, pp. 49-61.

Becker, B. and Huselid, M. (2006), Strategic Human Resources Management: where do we go from there? Journal of Management, 32, pp. 898-925.

Becton, J. and Schraeder, M. (2009), Strategic Human Resources Management: Are We There Yet? The Journal for Quality and Participation, 31, 4, pp. 11-18.

Birchfield, R. (2003), HR Management - the future of HR. What are the critical issues? New Zealand Management, pp.45.

Birdi, K., Clegg, C., Patterson, M., Robinson, A., Stride, C., Wall, T. and Wood, S. (2008), The Impact of Human Resource and Operational Management Practices on Company productivity: a longitudinal study, Personnel Psychology, 61, 3, pp. 467-501.

Boston Consulting Group/World Federation of Personnel Management Association (BCG/WFPMA)(2008), Creating People Advantage, How to address HR challenges worldwide through 2015, Boston Consulting Group, Inc and World Federation of Personnel Management Associations.

Boulton, R., Libert, D. and Samek, S. (2000), A business model for the new economy. The Journal of Applied Business Strategy, 21, 4, pp. 29-35.

Brewster, C., Farndale, E. and Ommeren, J. (2000), HR Competencies and Professional Standards, $W$ F P MA, Cranfield University, UK.

Chanda, A., Krishna, B. and Shen, J. (2007), Strategic Human Resources Technologies, keys to managing people, Sage Publications, New Delhi.

Chau, K. and Chan, A. (2005), Philosophical foundations of eminent Hong Kong Chinese CEOs' leadership, Journal of Business Ethics, 60, pp. 47-62.

Chow, I. (2004), The impact of institutional context on human resources management in three Chinese societies, Employee Relations, 26, 6, pp. 626-642.

Darien, S. (2005), Not Just Any Seat at the Table, Future of Human Resources Management: 64 thought leaders explore the critical HR issues of today and tomorrow, Society for Human Resources, John Wiley and Sons, Inc., Losey, M., Meisinger, S. and Ulrich, D. (Ed.), New Jersey.

Eldomiaty, T. and Chong, Y. (2006), Corporate governance and strategic transparency: East Asia in the international business systems, Corporate Governance, 6, 3, pp. 281-295.

Finnie, W. and Early, S. (2002), Result based leadership: an interview with Dave Ulrich, Strategic \& Leadership, 30, 6, 23-29.

Guest, D., Michie, J., Conway, N. and Sheehan, M. (2003), Human Resources Management and Corporate Performance in the UK, British Journal of Industrial Relations, 41, 2, pp. 291-314.

Hong Kong Institute of Human Resources (HKIHRM) (2008), HRM Strategies and Practices in Hong Kong Research Report, Hong Kong.

Hurtado, P. (2007), On the Ethical implications of the Relationship between types of research methodologies and theories of strategy formulation, Competition Forum, 5, 1, pp. 220-228.

Karami, A., Jones, B. and Kakabadse, N. (2008) Does strategic Human Resources management matter in high-tech sector? Some learning points for SME managers, Corporate Governance, $\mathbf{8}, 1$, pp. 7-17.

KPMG (2008), International Survey of Corporate Responsibility Reporting, accessed 26 April 2009, http://kpmg.nl/site,asp?id=2044\&process_mode=mode_mode_doc\&doc_id=46329 . 
Lam, S. and Schaubroeck, J. (1998), Integrating HR planning and organizational strategy, Human Resources Management Journal, 8, 3, pp. 5-19.

Marciano, V. (1995), The origins and development of human resources management, Academy of Management Journal, pp. 223-227.

Marr, B. (2005), Strategic management of intangible value drives, Handbook of Business strategy, pp. 147-154.

Mohrman, S. (2007), Designing Organizations for growth: the Human Resource Contribution, Human Resource Planning, 30, 4, pp.34-45.

Moss, B. (2008), Economic Crisis is a golden opportunity for OH and HR, Occupational Health, 60 , 11, pp. 10.

Nishii, L., Lepak, D. and Schneider, B. (2008), Employee attributions of the why of HR practices: their effects on employee attitudes and behaviours and customer satisfaction, Personnel Psychology, 61, 3, pp. 503-545.

O'Neil, L. (2009), HR's time to lead, HR Magazine, 54, 5, pp.8.

Ormanidi, O. and Stringa, O. (2008), Porter's model of Generic competitive strategies, Business Economics, 43, 4, pp. 55-64.

Othman, R., Abdul-Ghani, R. and Arshad, R. (2001), Great Expectations - CEO's perception of the performance gap of the HRM functions in the Malaysian manufacturing sector, Personnel Review, $\mathbf{3 0}, 1,61$.

Oxfam, (2008), Corporate Social Responsibility Survey of Hang Seng Index Constituent Companies , accessed 12 December 2008, http://www.oxfam.org.hk .

Papalexandris, N. and Panayotopoulou, L. (2004) Exploring the mutual interaction of societal culture and human resource management practices: Evidence from 19 countries, Employee Relations , 26, 5, pp. 495-509.

Pedrini, M. (2007), Human capital convergences in intellectual capital and sustainability reports, Journal of Intellectual Capital, 8, 2, pp. 346-366.

Petty, R., Ricceri, F., and Guthrie, J. (2008), Intellectual capital: a user's perspective , Management Research News, 31, pp. 434-447.

PricewaterhouseCoppers International Limited (PwC) (2008), The $11^{\text {th }}$ Annual Global CEO survey, accessed 7 May 2009, http://www.pwc.com/ceosurvey/key_findings.html.

RBL (2009), Human Resource Competency Study, accessed 6 June 2009, http://rbl.net/index.php/research.

Sheehan, C. and Scafidi, A. (2005), The strategic role of HR Managers in Australian Organizations: cues from Organizational recruitment sources, Journal of the Australian and New Zealand Academy of Management, 11, 1, pp. 41-48.

Spanos,Y., Zaralis, G. and Lioukas, S. (2004), Strategy and Industry effects on profitability: evidence from Greece, S trategic Management Journal, 25, 2, pp. 139-165.

Tamkin, P., Reilly, P. and Strebler, M. (2006), The changing HR function, the key questions, accessed 7 June 2009, http://www.cipd.co.uk/research/_chnghrfnn.htm?IsSrchRes=1 .

Tayles, M., Pike, R. and Sofian, S. (2007), Intellectual capital, management accounting practices and corporate performance; Perceptions of managers , Accounting, Auditing and Accountability Journal, 20, 4, pp. 522-548.

Ulrich, D. (1998), Delivering Results: a new Mandate for Human Resources Professionals, Harvard Business School Press, Boston.

Ulrich, D. (2005), HR: Dave Ulrich on how HR Directors can use people power to create value, Director, $\mathbf{5 9}, 3$, pp.33.

Vickers, M. (2007), HR Growing pains, getting awkward to accomplished, Human Resource Planning, 30, 4, pp.20-24.

Vuontisjarvi, T. (2006), The European Context for Corporate Social Responsibility and Human Resource Management: An analysis of the largest Finnish Companies, Business Ethics: A European Review, 15,3, pp.271-291. 
Walker, J. (2001), Human Capital: Beyond HR? Human Resource Planning , 24, 2, pp. 4-6.

Welford, R. (2004) Corporate Social Responsibility in Europe and Asia: Critical Elements and Best Practice, The Journal of Corporate Citizenship, 13, pp. 31-47.

Welford, R. (2005), Corporate Social Responsibility in Europe, North America and Asia: 2004 Survey Results, The Journal of Corporate Citizenship, 17, pp. 33-52.

Wright, P., Gardner, T. and Moynihan, M. (2003), The impact of HR practices on the performance of business units, Human Resource Management Journal, 13, 3, pp. 21-36.

Wyatt, A. (2008), What financial and non financial information on intangibles is value-relevant? A review of the evidence, Accounting and Business Research, 38, 3, pp. 217-256.

Wynter-Palmer, J. (2007), Do we need more a typical human resources persons? Journal of Eastern Caribbean Studies, 32, 4, pp. 51-61.

Yeung, A., Cheung, S., So, W., Lui, T. and Lui, S. (1998), Human Resources competencies in Hong Kong: Research findings and application guide, Hong Kong Institute of Human Resources, pp. 1- 47.

Younger, J., Smallwood, N. and Ulrich, D. (2007), Developing your organization's brand as a talent developer, Human Resources Planning, 30, 2, pp. 21-29.

\section{About the Authors}

Dr. Juni Chan

Juni Chan is a Human Resources Management Consultant in Krystal Group, Hong Kong. She has a proven record in executive coaching, management consultancy and talent management in Hong Kong and Asia Pacific regions. She is also a lecturer in undergraduate and postgraduate programs in Hong Kong and China for international universities.

\section{Prof. John Burgess}

John Burgess is a Professor with Newcastle Business School, the University of Newcastle, Australia. He has an extensive research record on employment developments, the labour market, gender and work, and labour regulation. He has examined the development of parttime work, casual work, home work and temporary agency work. 